\title{
Effect of Cu content on microstructures and mechanical properties of ADI treated by two- step austempering process
}

\author{
Peng-yue Yi, *Er-jun Guo, Li-ping Wang, Yi-cheng Feng, and Chang-liang Wang \\ School of Material Science and Engineering, Harbin University of Science and Technology, Harbin, China
}

\begin{abstract}
The effect of $\mathrm{Cu}$ content on the microstructures and mechanical properties (yield strength, ultimate tensile strength, impact energy, fracture toughness) of austempering ductile iron (ADI) treated by two-step austempering process were investigated. High $\mathrm{Cu}$ content in nodular cast irons leads to a significant volume fraction of retained austenite in the iron after austempering treatment, but the carbon content of austenite decreases with the increasing of $\mathrm{Cu}$ content. Moreover, austenitic stability reaches its maximum when the $\mathrm{Cu}$ content is $1.4 \%$ and then drops rapidly with further increase of $\mathrm{Cu}$. The ultimate tensile strength and yield strength of the ADI firstly increases and then decreases with increasing the $\mathrm{Cu}$ content. The elongation keeps constant at $6.5 \%$ as the $\mathrm{Cu}$ content increases from $0.2 \%$ to $1.4 \%$, and then increases rapidly to $10.0 \%$ with further increase $\mathrm{Cu}$ content to $2.0 \%$. Impact toughness is enhanced with $\mathrm{Cu}$ increasing at first, and reaches a maximum $122.9 \mathrm{~J}$ at $1.4 \% \mathrm{Cu}$, then decreases with the further increase of $\mathrm{Cu}$. The fracture toughness of ADI shows a constant increase with the increase of $\mathrm{Cu}$ content. The influencing mechanism of $\mathrm{Cu}$ on austempered ductile iron (ADI) can be classified into two aspects. On the one hand, Cu dissolves into the matrix and functions as solid solution strengthening. On the other hand, $\mathrm{Cu}$ reduces solubility of $\mathrm{C}$ in austenite and contributes more stable retained austenite.
\end{abstract}

Key words: Cu-alloyed ADI; two-step austempering process; mechanical properties; austenite stability
CLC numbers: TG143.5
Document code: A
Article ID: 1672-6421(2019)03-168-09

\begin{abstract}
$\mathrm{A}$ ustempered ductile iron (ADI) is widely used in automobile and machinery industries due to its excellent mechanical properties and low cost ${ }^{[1-6]}$. However, the shortage of ductility and toughness of ADI is still a major problem in application. Some attempts have been made to promote ductility and toughness of ADI by adding nickel, while maintaining high strength ${ }^{[7-9]}$. However, the soaring price of nickel limits its application in ADI. In addition, a two-step austempering process is also an effective way to balance the strength and toughness ${ }^{[8,9,21-27]}$.

$\mathrm{Cu}$ is a common strengthening alloy element for spheroidal graphite iron. Amran and Yan's research indicates that $\mathrm{Cu}$ may increase austenite fraction and its carbon content of ADI ${ }^{[10,11]}$. Batra studied the influence of $\mathrm{Cu}$ together with $\mathrm{Ni}$ and Mo on strength and fatigue performance of ADI. The result indicates that $\mathrm{Cu}$ can improve the strength of ADI ${ }^{[12,13]}$. Hsu and
\end{abstract}

\footnotetext{
*Er-jun Guo

Male, born in 1963, Ph.D., Professor. His research interests mainly focus on nodular ductile cast irons and cast steels.

E-mail: guoerjunees@163.com
}

Received: 2018-12-11; Accepted: 2019-01-31
Eric's research indicates that toughness is enhanced by $\mathrm{Cu}$ in ADI. Some research also shows the same results ${ }^{[14,15,18,20]}$. As above, $\mathrm{Cu}$ is an ideal strengthening element to replace nickel. However, there are few studies on the effect of $\mathrm{Cu}$ on the microstructures and mechanical properties of ADI treated by two-step austempering.

This research aims to study different $\mathrm{Cu}$ contents on microstructures and mechanical properties of ADI treated by a two-step austempering process. Four groups of samples with different $\mathrm{Cu}$ contents are prepared. OM, SEM and TEM were used for observing microstructure. Tensile test, impact test and plane strain fracture toughness test were all carried out to evaluate the mechanical properties of ADI. The strengthening mechanism of $\mathrm{Cu}$ in ADI is also discussed.

\section{Experimental procedure}

\subsection{Material and heat-treatment}

Chemical composition of the cast iron used in this experiment was $3.6 \% \mathrm{C}, 2.6 \% \mathrm{Si}, 0.4 \% \mathrm{Mn}$, and four groups of samples containing $0.2 \%, 0.8 \%, 1.4 \%$ and 
$2.0 \% \mathrm{Cu}$, respectively, were named as $\mathrm{C} 1, \mathrm{C} 2, \mathrm{C} 3$ and $\mathrm{C} 4$.

The alloy was melted in a $50 \mathrm{~kg}$ medium-frequency induction furnace at $1,500{ }^{\circ} \mathrm{C}-1,550{ }^{\circ} \mathrm{C}$. RE3Mg8 was used as nodularizer and $75 \mathrm{SiFe}$ as inoculant. The melted alloy was cast into the Y-shaped test blocks at about $1,300{ }^{\circ} \mathrm{C}$ after spheroidizing and inoculation. The Y-shaped block shown in Fig. 1(a) with a size of $25 \mathrm{~mm}$ in thickness and $165 \mathrm{~mm}$ in length was used for tensile and impact tests. The block shown in Fig. 1(b) with a size of $75 \mathrm{~mm}$ in thickness and $90 \mathrm{~mm}$ in length was used for plane strain fracture toughness test. It was averagely cut into three pieces with a thickness of $25.5 \mathrm{~mm}$ before austempering to eliminate the microstructure difference between two kinds of blocks caused by thickness difference. The sampling locations are also shown in Fig. 1.
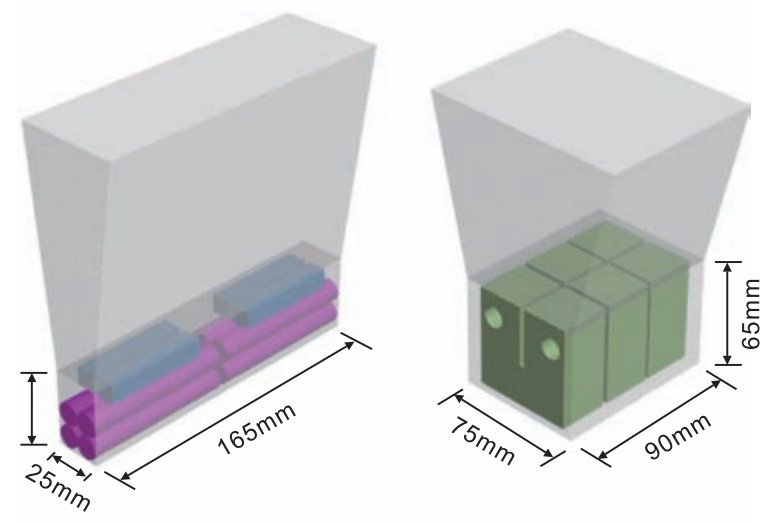

Fig. 1: Y-shaped block and sampling location: (a) block used for tensile and impact test; (b) block used for fracture toughness test

Heat treatment was conducted in a two-step austempering process optimized in a previous work ${ }^{[28]}$. All the samples were austenitized at $900{ }^{\circ} \mathrm{C}$ for $90 \mathrm{~min}$ in the furnace without gas protection, and then rapidly quenched into a salt bath at $280{ }^{\circ} \mathrm{C}$ for $15 \mathrm{~min}$. After that, the samples were immediately transferred to another salt bath at $320^{\circ} \mathrm{C}$ for $45 \mathrm{~min}$. Finally, these samples were air cooled to room temperature.

\subsection{Microstructure characterization}

Metallographic specimens were prepared by mechanical grinding followed by polishing, and then etched with $2 \%$ nital. The microstructure was observed by an optical microscope (GX71, OLYMPUS, Tokyo, Japan) and a scanning electron microscope (Quanta200, FEI, Eindhoven, The Netherlands) simultaneously to examine the morphology and distribution of austenite and ferrite. The transmission electron microscope (TEM) specimens were prepared by ion-milling (691, Gatan, Pleasanton, CA, USA) and examined in a transmission electron microscope (JEM-2100, JEOL, Tokyo, Japan) operating at $200 \mathrm{kV}$.

$\mathrm{X}$-ray diffraction (XRD) was used to calculate austenitic quantity and its carbon content. The X-ray diffractometer (D/ max-2600/PC, Rigaka, Japan) was employed with $\mathrm{Cu} K_{\alpha}$ radiation at $40 \mathrm{kV}$ and $150 \mathrm{~mA}$, and a scanning rate of $3{ }^{\circ} \mathrm{C} \cdot \mathrm{min}^{-1}$ in the range of $30-100^{\circ}$. The mechanical stability of austenite was evaluated by comparing the austenitic quantity variation from the result of XRD. The samples of XRD were cut from the places of fracture and far away from the fracture. The size of the specimen was $10 \mathrm{~mm} \times 10 \mathrm{~mm} \times 1.5 \mathrm{~mm}$. The volume fraction of the retained austenite was estimated using the following relationship:

$$
\frac{I_{\gamma\{\mathrm{hk} 1\} i}}{I_{\alpha\{\mathrm{hkl}\} j}}=\frac{R_{\gamma\{\mathrm{hkl}\}} X_{\gamma}}{R_{\alpha\{\mathrm{hkl}\}} X_{\alpha}}
$$

where $I_{\gamma\{\mathrm{hkl}\} \mathrm{i}}$ and $I_{\alpha\{\mathrm{hkl}\} \mathrm{j}}$ are the integrated intensities of a given $\{h k l\}$ plane from the austenite and ferrite, respectively. $X_{\gamma}$ and $X_{\alpha}$ are the volume fraction of austenite and ferrite, $\frac{R_{\gamma\{\hat{k} \mathrm{kl} l}, i}{R_{\alpha\{\mathrm{hk} l\}_{j}}}$ was the ratio of intensity factor corresponding to the crystal plane of $\{\mathrm{hkl}\}_{i}$ from austenite and $\{\mathrm{hkl}\}_{j}$ from ferrite. The $\{200\},\{220\}$ and $\{311\}$ planes of austenite and $\{200\}$ and $\{211\}$ planes of ferrite were used to analyze the volume fraction of austenite.

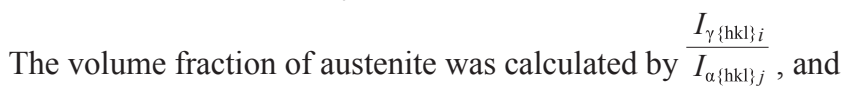
the result was the average of six values. The carbon content of austenite was determined by the equation:

$$
a_{\gamma}=0.358+0.0044 C_{\gamma}
$$

where $a_{\gamma}$ was the lattice parameter of austenite (nm) and $C_{\gamma}$ the carbon content of austenite (wt.\%).

\subsection{Mechanical properties test}

Tensile testing was performed according to the Standard GB/T 228.1-2010 in an electronic universal testing machine (44300, CCS, Changchun, China). Specimens were machined according to Standard GB/T 24733-2009, and the gauge diameter was 35 $\mathrm{mm}$ and $7 \mathrm{~mm}$. Tensile strength, yield strength and percentage elongation values were obtained in this test, and the values were the average of three tests.

An unnotched Charpy impact test was performed according to Standard GB/T 229-2007 on a pendulum impact testing machine (NI300, NCS, Beijing, China) at room temperature. The size of the specimen was $10 \mathrm{~mm} \times 10 \mathrm{~mm} \times 55 \mathrm{~mm}$. The impact energy result was an average value of the highest five test values of six test samples.

Plane fracture toughness was completed according to Standard GB/T 4161-2007 in a servo-hydraulic test system (MTS-810, MTS Systems Corporation, USA). The compact tension (CT) specimen was $25 \mathrm{~mm}$ in thickness and $50 \mathrm{~mm}$ in effective width. CT specimens were ground and polished with 800 -grit waterproof sand paper and then were pre-cracked in fatigue at a $\Delta K$ level of $10 \mathrm{MPa} \cdot \mathrm{m}^{1 / 2}$ to produce a $2 \mathrm{~mm}$ long crack. The fracture toughness result was the average value from three tests.

Fracture surfaces of impact specimens and CT specimens were examined under SEM to elicit information on fracture mechanism.

\section{Result}

\subsection{Microstructure}

Figure 2 shows the microstructure in as-cast state. Graphite nodules are relatively random and uniformly distributed. The nodularity of each sample is remaining around $90 \%$. No obvious 

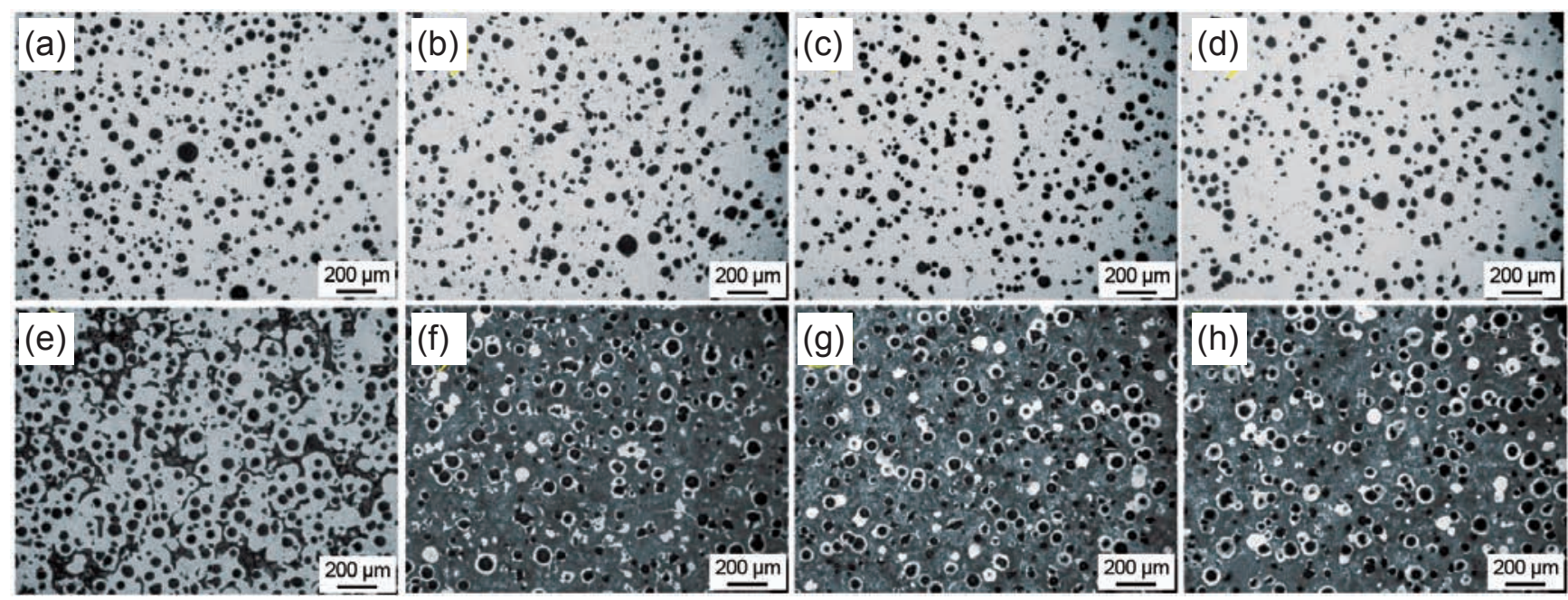

Fig. 2: Optical microstructures of as-cast nodular graphite iron: (a) and (e) C1; (b) and (f) C2; (c) and (g) C3; (d) and (h) C4

change can be found on both morphology and size of graphite nodules with the increase of $\mathrm{Cu}$ content. This indicates that graphite nodules are not influenced by $\mathrm{Cu}$, and the change of mechanical properties is not related to graphite nodules either. The quantity of pearlite increases obviously from $20 \%$ to $85 \%$ as $\mathrm{Cu}$ increasing from $0.2 \%$ to $0.8 \%$, and it maintains at roughly $85 \%$ with further increase of $\mathrm{Cu}$.

Figure 3 shows the optical microstructure of ADI with different $\mathrm{Cu}$ contents after austempering. The samples exhibit similar microstructures consisting of acicular ferrite, ferrite bunch (paralleled arranged ferrite lath and film-like austenite) and blocky retained austenite. Figure 4 shows the SEM images of ADI with different $\mathrm{Cu}$ contents after austempering. The ferrite bunch and blocky austenite are easily observed, while the coarse acicular ferrite is hardly distinguished. This is because the acicular ferrite is also consisted of many refined paralleled ferrite laths as circled in the figure. The content and size of austenite increase with an increase in $\mathrm{Cu}$ content. Furthermore, TEM was carried out to characterize the microstructure of ADI (Fig. 5). The result shows that the thickness of refined ferrite lath (marked by white arrow) is only around $80 \mathrm{~nm}$ and the thickness remains constant with the increase of $\mathrm{Cu}$. However, the thickness of austenite (marked by yellow arrow) distributed in ferrite bunch changes from 40 to $120 \mathrm{~nm}$ as $\mathrm{Cu}$ increases from $0.2 \%$ to $2.0 \%$.

Figure 6 shows the variation of austenite content fraction $\left(X_{\gamma}\right)$ and carbon content $\left(C_{\gamma}\right)$ of austenite with the $\mathrm{Cu}$ increasing. $X_{\gamma}$ increases with an increase of $\mathrm{Cu}$ before fracture, and reaches the maximum of $27.79 \%$ as $\mathrm{Cu}$ addition increasing to $2.0 \%$, while $C_{\gamma}$ monotonically reduces with increasing $\mathrm{Cu}$. Moreover, comparing to the $C_{\gamma}$ before fracture [solid line in Fig. 6(b)], the carbon content of austenite increases obviously after fracture
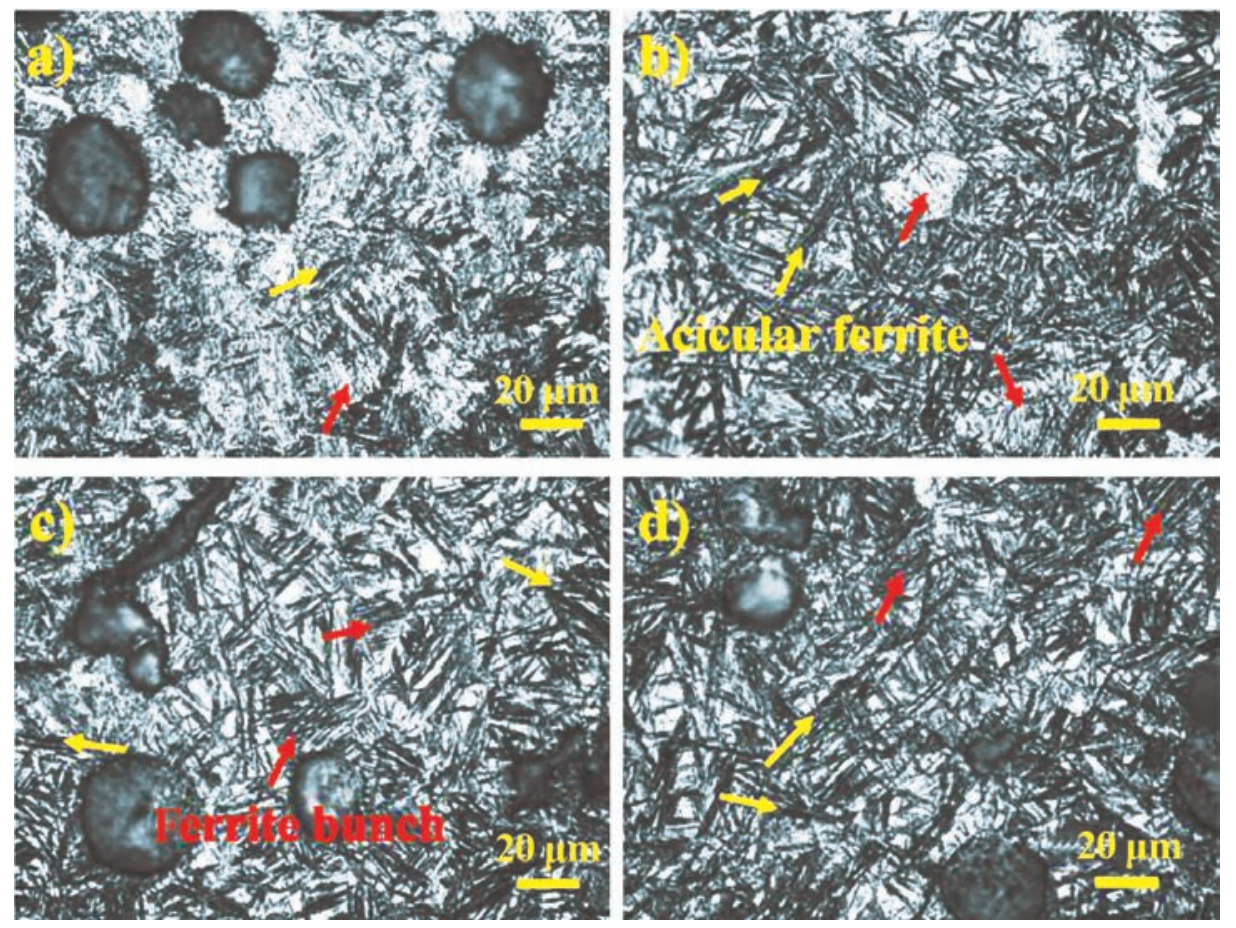

Fig. 3: Optical microstructures of nodular graphite iron after austempering: (a) C1; (b) C2; (c) C3; (d) C4. 

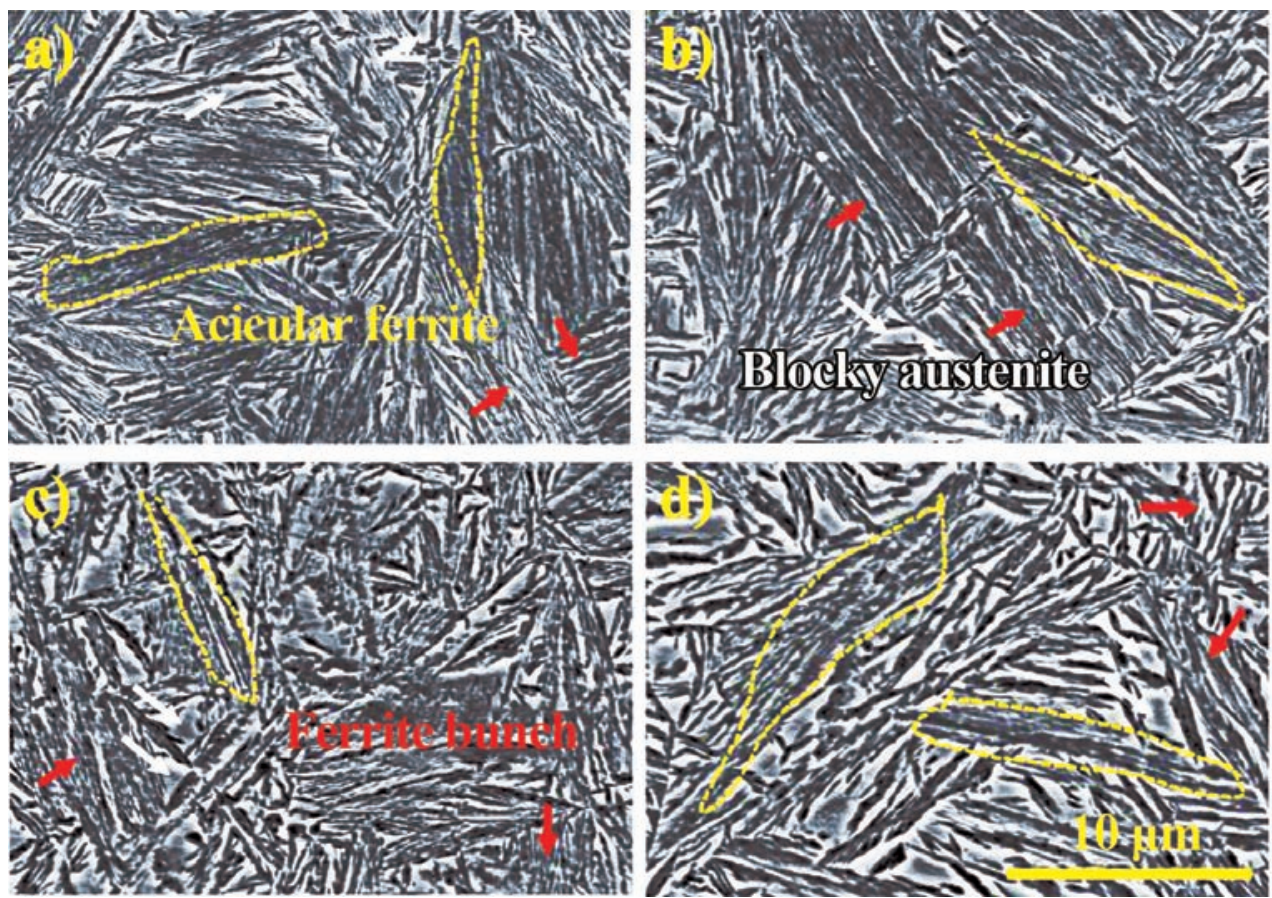

Fig. 4: SEM micrograph images of nodular graphite iron after austempering: (a) C1; (b) C2; (c) C3; (d) C4
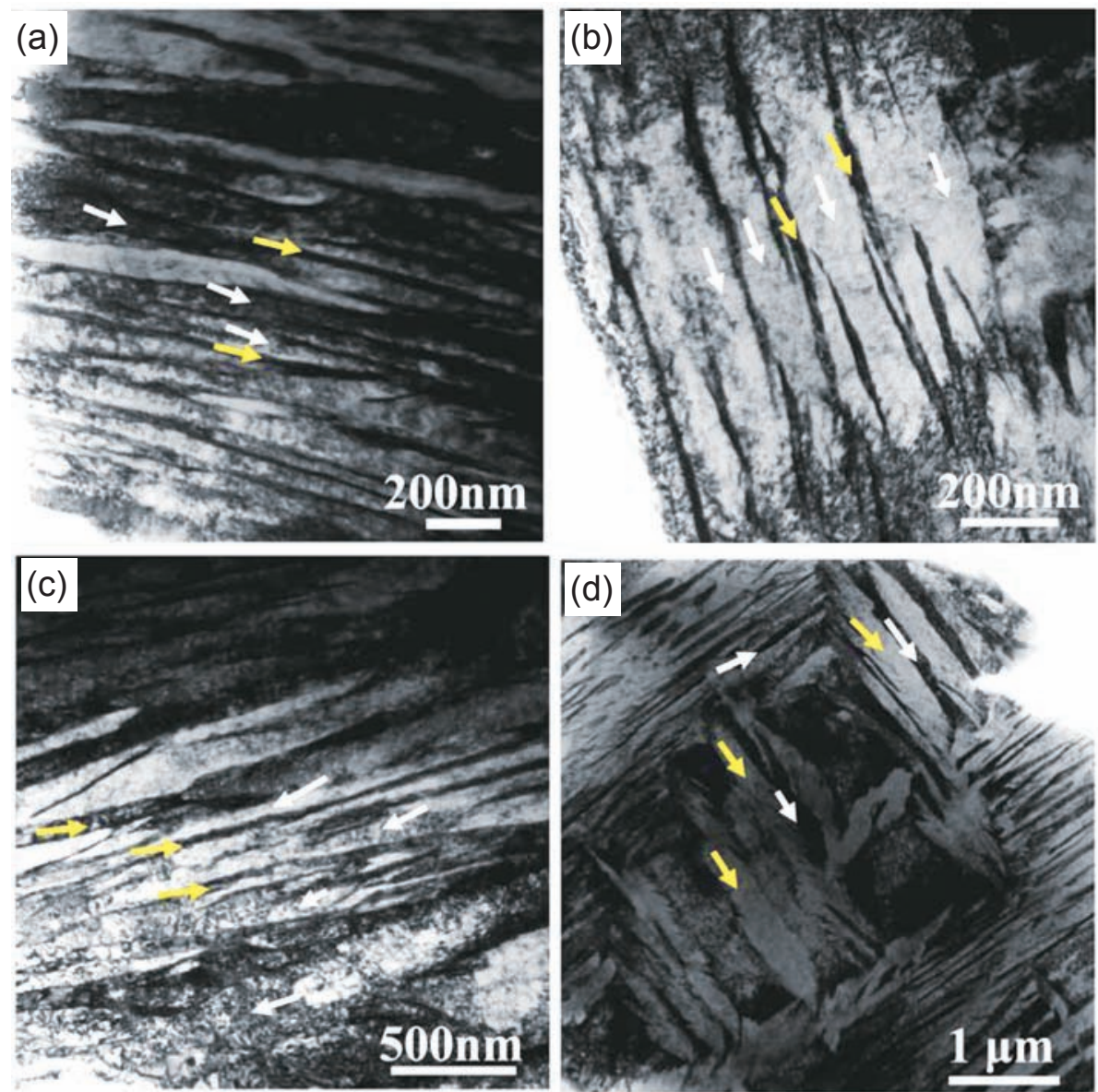

Fig. 5: TEM micrograph of nodular graphite iron after austempering: (a) C1; (b) C2; (c) C3; (d) C4

[dashed line in Fig. 6(b)]. This indicates inhomogeneous distribution of carbon in retained austenite. Because the carbon atoms cannot diffuse to austenite during fracture, the increase of $C_{\gamma}$ is caused by low-carbon austenite transforming to martensite during fracture. Meanwhile, the high-carbon austenite is still retained after fracture, the $C_{\gamma}$, an average value of carbon content of austenite, increases. Moreover, the $\Delta X_{\gamma}$ decrease indicates that the inhomogeneous distribution trend is effectively restrained when $\mathrm{Cu}$ content increases from $0.2 \%$ to $1.4 \%$. 

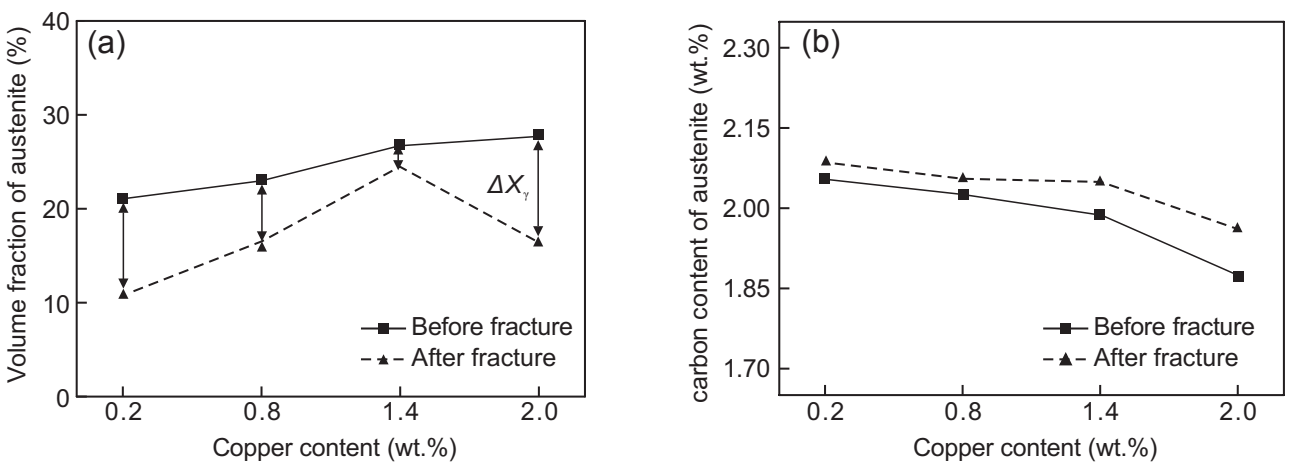

Fig. 6: X-Ray diffraction result of ADI with different $\mathrm{Cu}$ contents before and after fracture: (a) austenite content, (b) austenite carbon content

\subsection{Mechanical properties}

Figure 7 shows the influence of $\mathrm{Cu}$ content on mechanical properties of two-step ADI. Tensile strength and yield strength are merely $1,135 \mathrm{MPa}$ and $935 \mathrm{MPa}$ in $\mathrm{C} 1$. As $\mathrm{Cu}$ increases from $0.2 \%$ to $0.8 \%$, the tensile strength and yield strength increase and reach a maximum of $1,420 \mathrm{MPa}$ and 1300 $\mathrm{MPa}$ in $\mathrm{C} 2$, and slowly decrease with further increase of $\mathrm{Cu}$. Elongation remains constant at about $6.5 \%$ when $\mathrm{Cu}$ content is less than $1.4 \%$ but increases rapidly to $10.0 \%$ when the $\mathrm{Cu}$ content is $2.0 \%$.
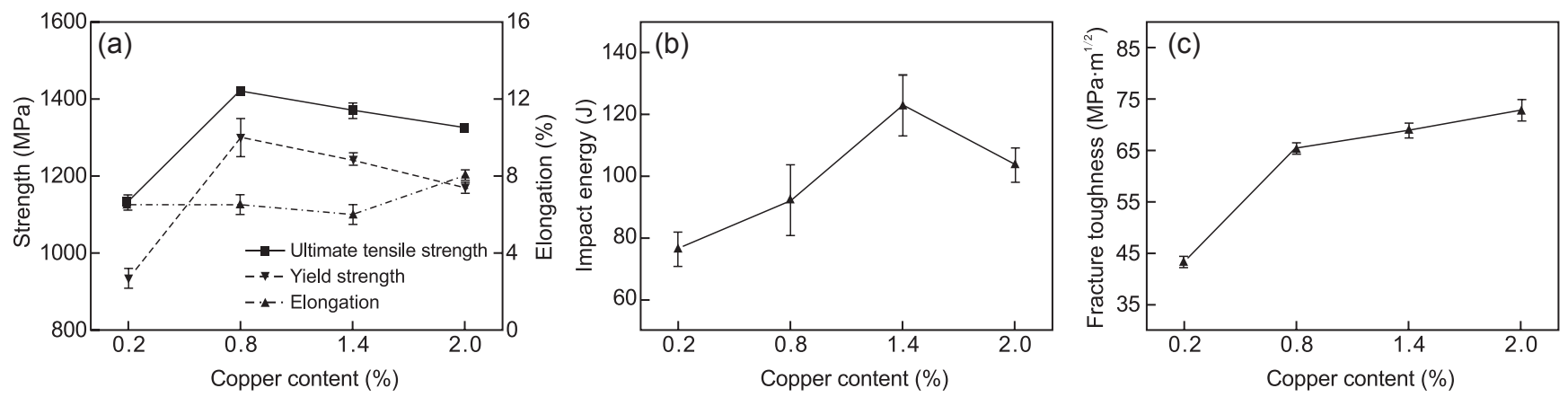

Fig. 7: Influence of $\mathrm{Cu}$ on mechanical properties: (a) tensile strength, (b) impact energy, (c) fracture toughness

The impact energy of ADI firstly increases and then decreases with increasing $\mathrm{Cu}$ content. When the $\mathrm{Cu}$ content is $1.4 \%$, the impact energy reaches its maximum of $122.9 \mathrm{~J}$ and then drops rapidly with further increase of $\mathrm{Cu}$ content. Furthermore, compared to the undeformed samples, the $X_{\gamma}$ of fractured samples decreases significantly [Fig. 6(a)]. This is because the deformation during fracture induced martensite transformation. Some unstable austenite transforms to martensite, and $\Delta X_{\gamma}$ decreases as $\mathrm{Cu}$ increases from $0.2 \%$ to $1.4 \%$. With further increasing of $\mathrm{Cu}, \Delta X_{\gamma}$ increases, indicating that the quantity of unstable austenite increases in $\mathrm{C} 4$.

Plane strain fracture toughness monotonically increases with increasing $\mathrm{Cu}$ from $43.36 \mathrm{MPa} \cdot \mathrm{m}^{1 / 2}$ to maximum $72.75 \mathrm{MPa} \cdot \mathrm{m}^{1 / 2}$ at $\mathrm{Cu} 2.0 \%$ [Fig. 7(c)].

\section{Discussions}

\subsection{Austenitic microstructure and stability}

The multiphase microstructure is an important characteristic of two-step ADI. Generally, it is consisted of ferrite and austenite. As shown in Fig. 4, the ferrite is almost unchanged with the increase of $\mathrm{Cu}$. The morphology and quantity of austenite are changed significantly with $\mathrm{Cu}$ content increasing. The blocky austenite becomes coarser and larger, and its quantity also increases. The film-like austenite becomes thicker and coarser. These evidences directly reveal that austenite is influenced by $\mathrm{Cu}$.

Simultaneously, $X_{\gamma}$ rises with Cu increasing [Fig. 6(a)]. This is because the primary austenite is strengthened by $\mathrm{Cu}$. Therefore, the bainite transformation is delayed ${ }^{[29,30]}$. Meanwhile, the austenitic phase region is amplified with the increase of $\mathrm{Cu}$. Therefore, in the same austempering condition, the undercooling degree of austenite and phase transformation driving force is reduced with increasing of $\mathrm{Cu}$ content. Hence, more austenite is retained in the end of the reaction, and ferrite nucleation is also suppressed.

In addition to the microstructure of austenite, the stability is also influenced by $\mathrm{Cu}$. Figure 8 shows the microstructure of $\mathrm{C} 1$. A new film-like phase can be observed between ferrite layers [Fig. 8 (a) and (b)]. The HRTEM and FFT pattern shows that the new phase has the same structure as $\theta$-carbide [Fig. 8 (c) and (d)]. It is an upper bainite structure obtained by decomposition of austenite ${ }^{[31]}$, which leads to a decrease in strength and plasticity. But this film-like $\theta$-carbide does not present in other samples. This indicates that the stability of austenite increases with increasing $\mathrm{Cu}$ content.

Moreover, an ordered phase can be observed at the grain boundary of $\mathrm{C} 1$ [Fig. 9(a)]. This ordered phase is mainly composed of $\mathrm{Fe}_{4} \mathrm{C}$ [Fig. 9(b)], which is formed by the aging 

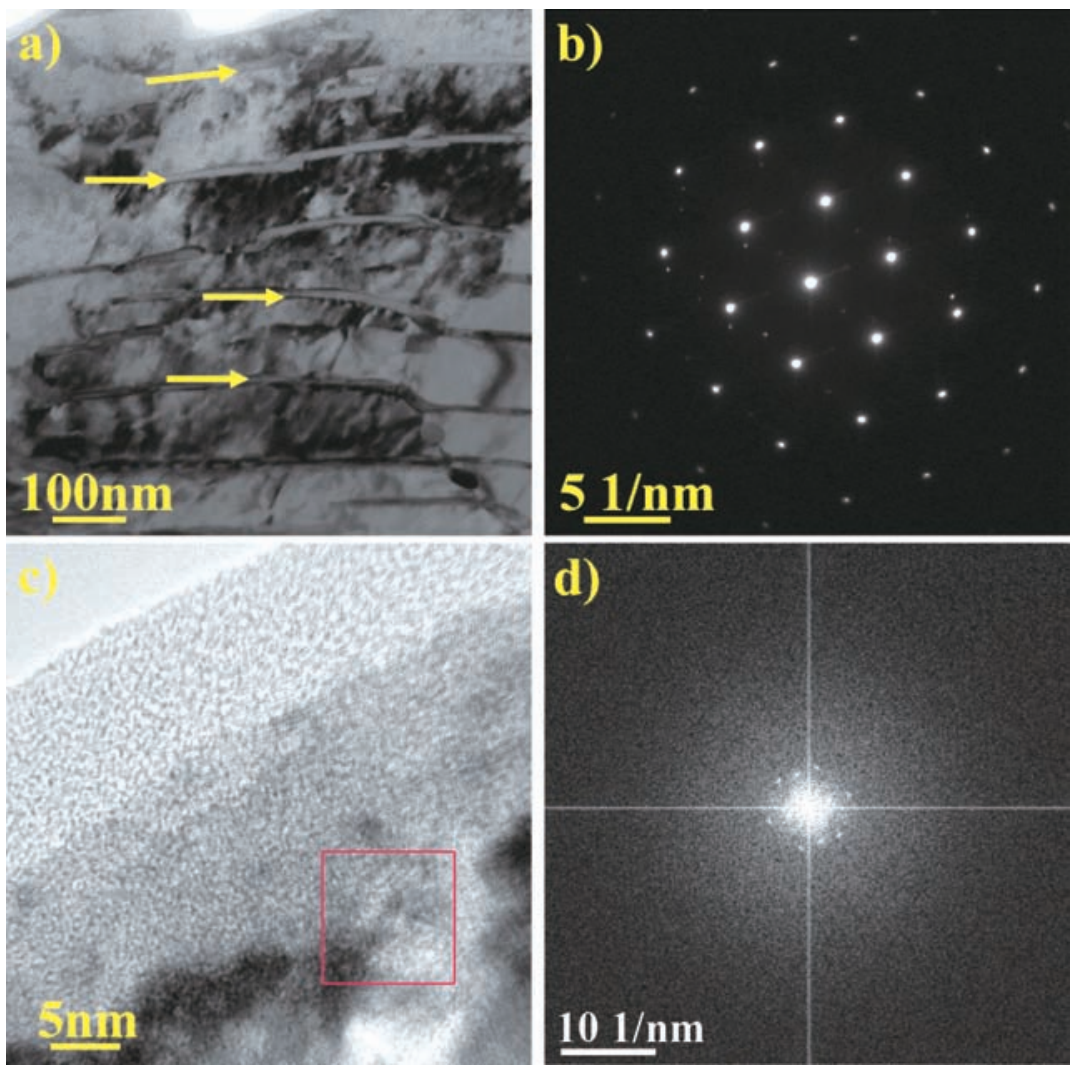

Fig. 8: A region of $\mathrm{C} 1$ containing different phases under TEM: (a) microstructure; (b) SAED pattern; (c) HREM of tip of film-like phase; (d) FFT pattern of selected area in (c)
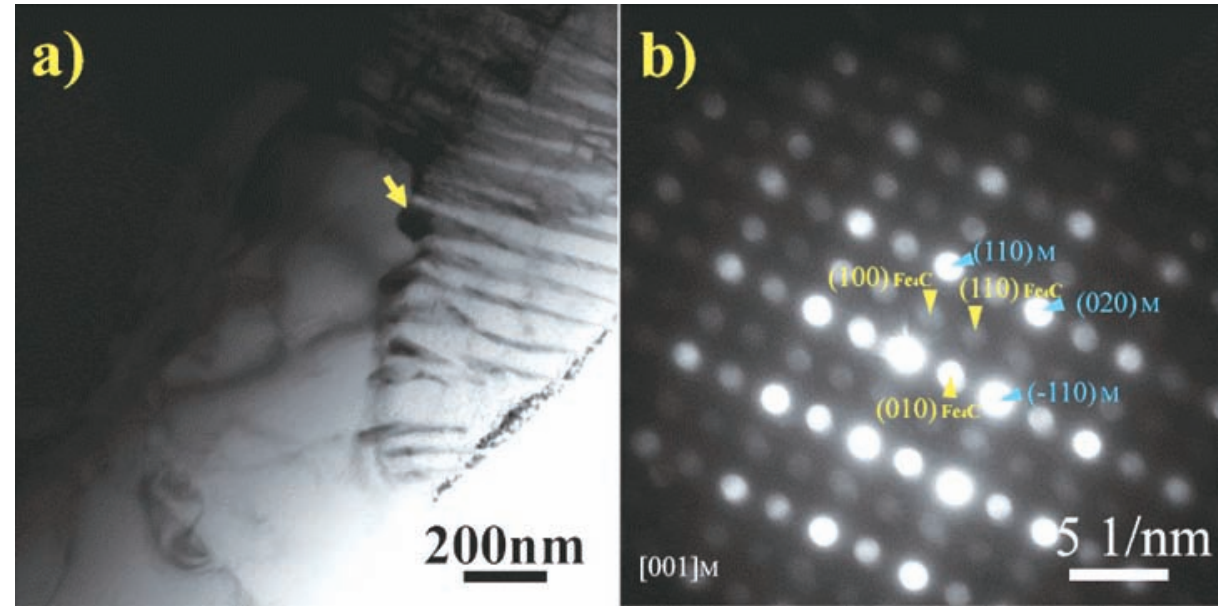

Fig. 9: Martensite at grain boundary of C1: (a) TEM bright field image; (b) SAED pattern of this region

of martensite at room temperature ${ }^{[32,33]}$. This shows that some austenite has transformed to martensite during the cooling down to room temperature. This martensite is transformed from the low carbon austenite due to the inhomogeneous distribution of carbon. Because the diffusion ability of carbon atoms increases with the increase of $\mathrm{Cu}$ content, this thermal unstable phenomenon only occurs in $\mathrm{C} 1$ samples with low $\mathrm{Cu}$ content.

In addition, the change of transformed austenite $\left(\Delta X_{\gamma}\right)$ amount shows that deformation-induced transformation indeed occurred in ADI during impact fracture [Fig. 6(a)]. It is evident that the resistance of deformation-induced transformation is increased as $\mathrm{Cu}$ increases from $0.2 \%$ to $1.4 \%$, indicating $\mathrm{Cu}$ promotes austenitic mechanical stability. However, $\Delta X_{\gamma}$ is drastically increased in C4. It cannot indicate that austenitic stability decreases due to the further increasing of $\mathrm{Cu}$. On the contrary, it is a result of $\mathrm{Cu}$ increasing the austenitic stability owing to that $\mathrm{Cu}$ delays the transformation reaction as mentioned earlier. In the same austempering condition, the bainitic reaction peak of C4 is not reached. Therefore, carbon enrichment from ferrite to austenite is still insufficient, and retained austenite is only thermally stable at room temperature. As deformation increases during fracture, austenite is not stable enough to resist martensite transformation ${ }^{[34-37]}$.

The main mechanism responsible for austenitic stability (thermal and mechanical) improvement can be ascribed to the solid solution of $\mathrm{Cu}$ and the decrease of activity of $\mathrm{C}$ caused by 
$\mathrm{Cu}$. More dissolved $\mathrm{Cu}$ atoms strengthen the primary austenite, which increase the austenitic stability ${ }^{[10]}$. Moreover, $\mathrm{Cu}$ reduces solubility of $\mathrm{C}$ in austenite, and promotes more $\mathrm{C}$ atoms diffuse to more austenite, which results more stable austenite retained in matrix. At the same time, $\mathrm{Cu}$ dissolved in ferrite may cause more dislocations, which trap more $\mathrm{C}$ atoms. Both of these behaviors can limit the activity of $\mathrm{C}$ and improve the stability of austenite.

\subsection{Mechanical properties strengthening mechanism}

In general, fine grains and more hardened phases will lead to a higher strength in ADI. However, the strength of ADI increases with the austenite content increasing when the copper content is between $0.2 \%$ and $0.8 \%$ [Fig. 6(a) and Fig. 7(a)]. This is because the microstructure constitution of $\mathrm{C} 1$ is more complicated. The parallel and alternative ferrite and $\mathrm{Fe}_{3} \mathrm{C}$ lamella is an upper bainite structure in essence, combined with the high-carbon martensite, the strength of $\mathrm{C} 1$ is the lowest with the minimum $\mathrm{Cu}$ content. As dissolved $\mathrm{Cu}$ atoms are increasing, dislocation density increases, with the result that more carbon atoms were trapped in. These trapped carbon atoms near the dislocation form a Cottrell atmosphere, and then pin the dislocation movement. Therefore, the ferrite is strengthened as $\mathrm{Cu}$ increases. Moreover, the ferrite substructure variation caused by $\mathrm{Cu}$ solid solution can also strengthen the ADI. When $\mathrm{Cu}$ is over $0.8 \%$, further dissolved $\mathrm{Cu}$ may strengthen the primary austenite and retain more austenite in the matrix rather than introducing more dislocations and Cottrell atmosphere in the ferrite. Hence, the strength of ADI decreases with further increase of $\mathrm{Cu}$ content. So, solid solution and dislocation strengthening are the major mechanisms, while the effect of fine grains is limited. Therefore, $\mathrm{C} 1$ cannot exhibit a high strength despite its fine grain size.
As it is known, plasticity may increase due to an austenitic transformation induced plasticity (TRIP) effect during deformation. Therefore, the elongation can be described by Eq. (2) without considering the weakness of graphite nodules.

$$
\delta \approx \delta_{0}+\delta_{\text {TRIP }}
$$

where $\delta_{0}$ is the essential plasticity of ausferrite, and $\delta_{\text {TRIP }}$ is the increment of plasticity induced by TRIP effect. Combined with $X_{\gamma}$ variation as shown in Fig. 6(a) and austenitic stability information discussed in previous section, $\delta_{0}$ is monotonic increasing with $X_{\gamma}$. However, $\delta_{\text {TRIP }}$ decreases with $\Delta X_{\gamma}$ reduction as $\mathrm{Cu}$ increases from $0.2 \%$ to $1.4 \%$, which makes up for the deficiency of $\delta_{0}$ at a lower $\mathrm{Cu}$ content and results in the equality of elongation in each sample. Then, elongation significantly increases in C4 caused simultaneously by peaking $\delta_{0}$ and $\delta_{\text {TRIP. }}$.

Toughness is also influenced by strain-induced martensite transformation behavior during fracture. The collaborative strain capacity of high-carbon martensite is far weaker than austenite ${ }^{[40]}$, which will change the state of stress-strain for crack tip, resulting in the damage of deformation ability. Simultaneously, volume expansion of martensite also increases lattice distortion and interface energy, which promotes crack initiation and propagation. In addition, more $X_{\gamma}$ can also improve the toughness of ADI. This is the reason that the impact energy of $\mathrm{C} 4$ is much higher than $\mathrm{C} 1$ and $\mathrm{C} 2$.

The fracture morphology of impact specimens is shown in Fig. 10. A characteristic cleavage fracture consisting of cleavage plane and river pattern is present in the fracture surface of C1. A small deformation was observed in the matrix around the graphite sphere. As $\mathrm{Cu}$ increases, fracture morphology is changed from river pattern to cleavage plane and tearing ridge, and the deformation around graphite nodule is increased
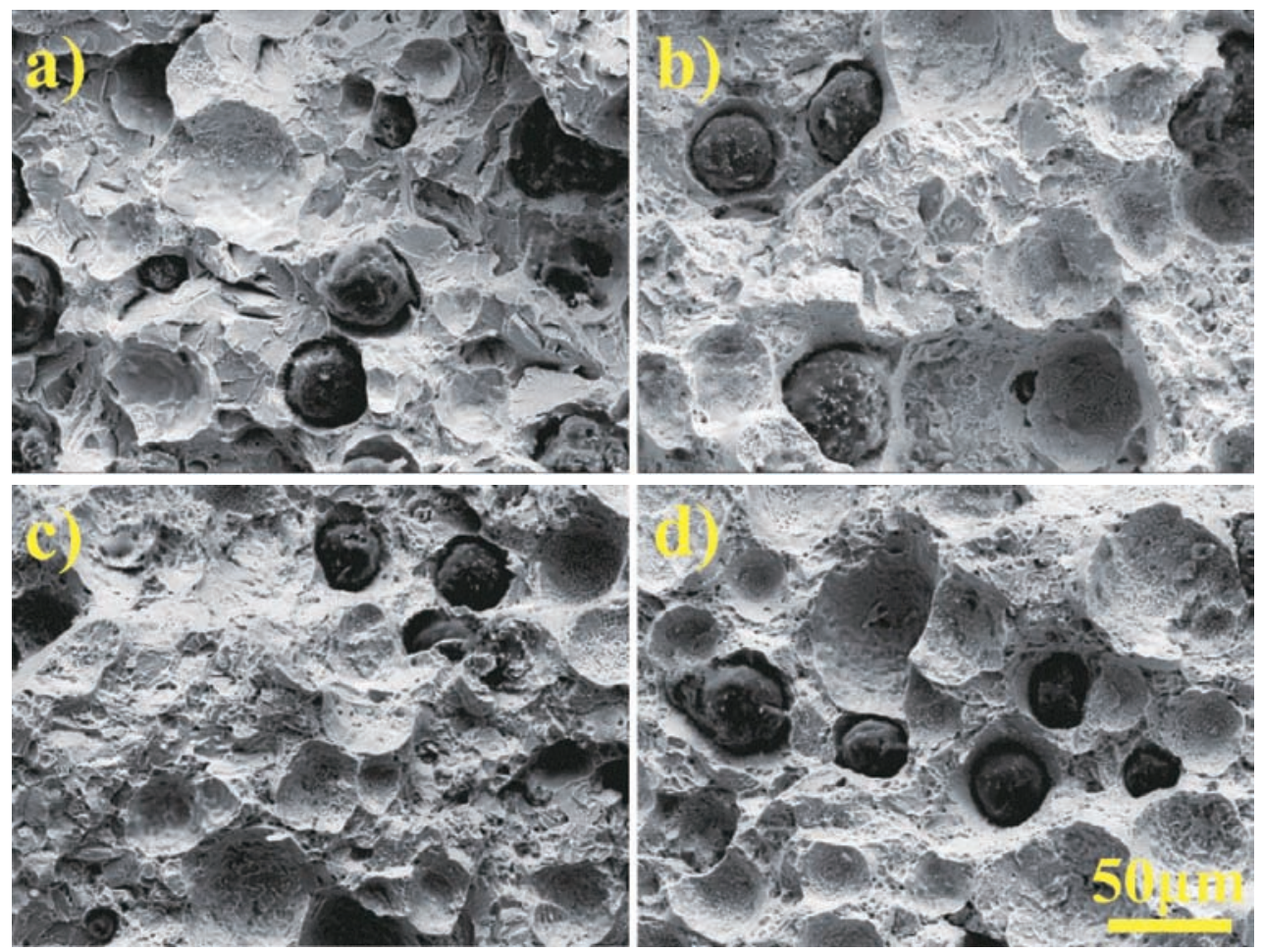

Fig. 10: Fractograph of impact samples of ADI with different Cu contents: (a) C1; (b) C2; (c) C3; (d) C4 
pronouncedly. Cleavage plane has disappeared in the fracture surface of $\mathrm{C} 4$, and many dimples are present around graphite nodules. Fracture mechanism changes from brittle to quasicleavage and then eventually transforms to ductile with increasing of $\mathrm{Cu}$.

The plane strain fracture toughness, $K_{\mathrm{IC}}$, increases with the increase of $X_{\gamma}$. This is a result of plastic deformation being limited to a very small region due to the sufficient thickness of CT samples. Strain-induced martensite content is too low to influence stress distribution at crack tip. Therefore, the "shielding" effect on crack propagation of austenite can be fully utilized. Therefore, $K_{\mathrm{IC}}$ reaches its maximum when the $\mathrm{Cu}$ content is $2.0 \%$.

Figure 11 exhibits the fracture surface morphology of CT specimens. A large number of river patterns can be observed in the fracture of $\mathrm{C} 1$. With increasing the $\mathrm{Cu}$ content, more tearing ridges and fewer cleavage planes presented in the fracture. Moreover, the deformation of graphite nodules increases with the increase of copper content because of the loading condition. The fracture mechanism with increase of $\mathrm{Cu}$ is changed from brittle cleavage to quasi-cleavage, which is similar to impact fracture.
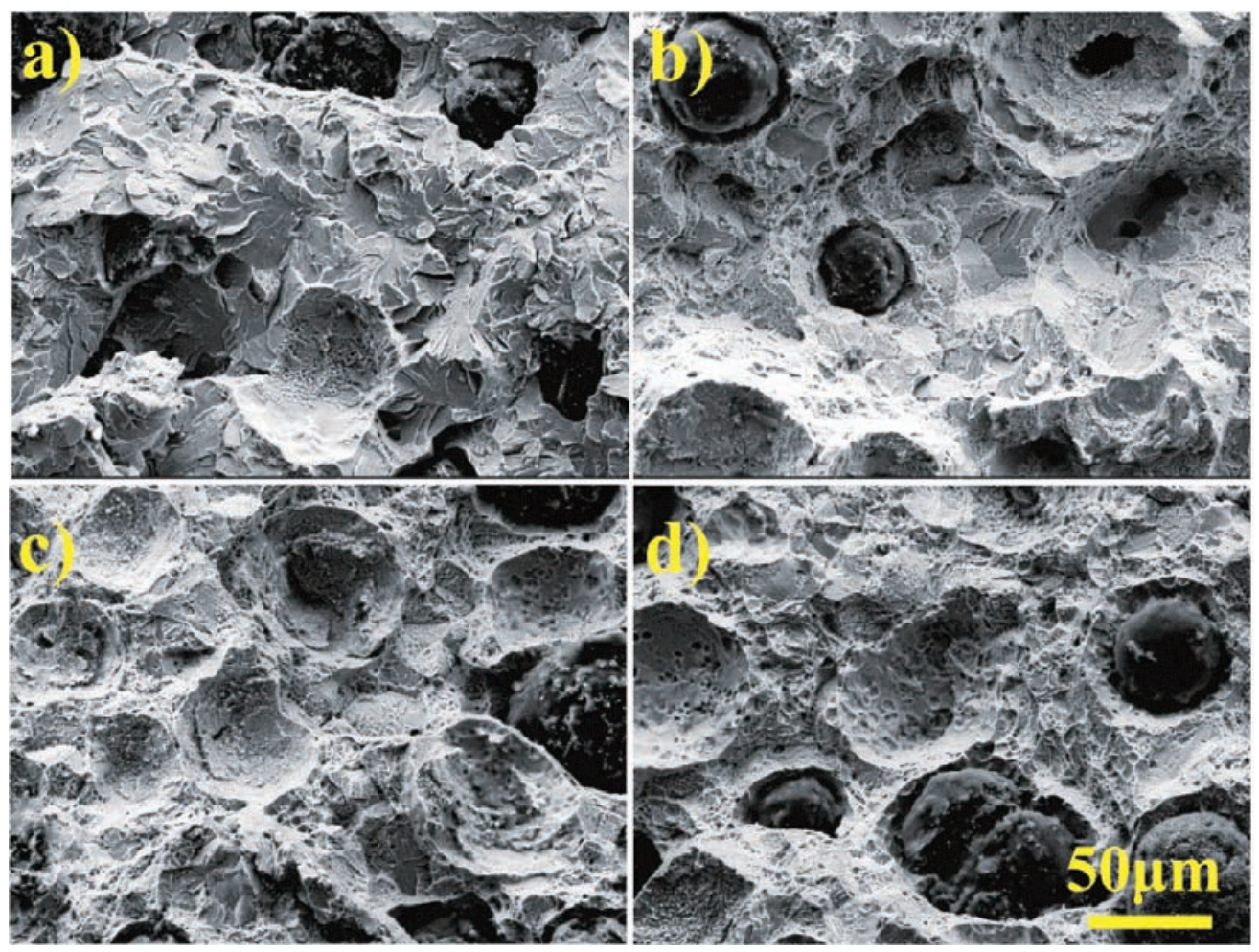

Fig. 11: Fractography of CT samples of ADI with different Cu: (a) C1; (b) C2; (c) C3; (d) C4

\section{Conclusions}

(1) The matrix of two-step ADI containing different $\mathrm{Cu}$ contents is consisted of different morphologies of ferrite bunch and austenite. As $\mathrm{Cu}$ increases, the retained austenite increases, the austenite film is thickened, and the size and amount of blocky austenite increase. Moreover, as $\mathrm{Cu}$ content increases from $0.2 \%$ to $1.4 \%$, the upper bainite and martensite are eliminated, so the stability of austenite is enhanced, while, when $\mathrm{Cu}$ content is over $1.4 \%$, the stability of austenite drops dramatically.

(2) Tensile strength and yield strength obviously increase as $\mathrm{Cu}$ increases from $0.2 \%$ to $0.8 \%$ owing to the elimination of upper bainite. With further increasing of $\mathrm{Cu}$, tensile strength and yield strength decrease because of ferrite content reduction and coarsening. Impact toughness increases first as $\mathrm{Cu}$ increases from $0.2 \%$ to $1.4 \%$, and then decreases with further increase of $\mathrm{Cu}$. Fracture toughness increases with the increase of $\mathrm{Cu}$ and austenite. This is because austenite can prevent crack propagation in a low tensile rate, and suppress the strain-induce transformation during loading.

(3) The influencing mechanism of $\mathrm{Cu}$ on the microstructure and mechanical properties of ADI can be divided into two aspects. On the one hand, $\mathrm{Cu}$ dissolves into austenite and ferrite causing solid solution strengthening; on the other hand, $\mathrm{Cu}$ reduces solubility of $\mathrm{C}$ in austenite, and contributes more stable retained austenite.

\section{References}

[1] Blackmore R A, Harding R A. The Effects of Metallurgical Process Variables on the Properties of Austempered Ductile Irons. Journal of Heat Treating, 1984, 3: 310-325.

[2] Fuller A G. Austempered Ductile Irons-Present Applications. Materials \& Design, 1985, 6: 127-130.

[3] Hughes I C H. Austempered Ductile Irons- their Properties and Significance. Materials \& Design, 1985, 6: 124-126.

[4] Kuna M, Springmann M, Mädler K, et al. Fracture mechanics based design of a railway wheel made of austempered ductile iron. Engineering Fracture Mechanics, 2005, 72: 241-253. 
[5] Lefevre J, Hayrynen K L. Austempered Materials for Powertrain Applications. Journal of Materials Engineering and Performance, 2013, 22: 1914-1922.

[6] Takahashi T, Abe T, Tada S. Effect of Bainite Transformation and Retained Austenite on Mechanical Properties of Austempered Spheroidal Graphite Cast Steel. Metallurgical and Materials Transactions A, 1996, 27: 1589-1598.

[7] Hernández-Rivera J L, Campos Cambranis R E, Garza A d I. Study of microstructural evolution and mechanical properties exhibited by non alloyed ductile iron during conventional and stepped austempering heat treatment. Materials \& Design, 2011, 32: 4756-4762.

[8] Yang J, Putatunda S K. Improvement in strength and toughness of austempered ductile cast iron by a novel two-step austempering process. Materials \& Design, 2004, 25: 219-230.

[9] Yang J, Putatunda S K. Influence of a novel two-step austempering process on the strain-hardening behavior of austempered ductile cast iron (ADI). Materials Science and Engineering: A, 2004, 382: 265-279.

[10] Yogev A, Alexander K, Peter S, etc. Influence of Copper Addition and Temperature on the Kinetics of Austempering Ductile Iron. Metallurgical and Materials Transactions B, 2010, 41: 1052-1058.

[11] Yan M. Effect of $\mathrm{Cu}, \mathrm{Mo}, \mathrm{Si}$ on the content retained austenite of austempered ductiled iron. Scripta Metllurgica et Materialia,1995, 32:1313-1317.

[12] Bahmani M, Elliott R. The austempering kinetics and mechanical properties of an austempered Cu-Ni-Mo-Mn alloyed ductile iron. Journal of Materials Science, 1997, 32: 4783-4791.

[13] Bahmani M, Elliott R. The relationship between fatigue strength and microstructure in an austempered $\mathrm{Cu}-\mathrm{Ni}-\mathrm{Mn}-\mathrm{Mo}$ alloyed ductile iron. Journal Of Materials Science, 1997, 32: 53835388.

[14] Batra U, Ray S, Prabhakar S R. The Influence of Nickel and Copper on the Austempering of Ductile Iron. Journal of Materials Engineering and Performance, 2004, 13: 64-68.

[15] Batra U, Ray S, Prabhakar S R. Austempering and Austempered Ductile Iron Microstructure in Copper Alloyed Ductile Iron. Journal of Materials Engineering and Performance, 2003, 12: 426-429.

[16] Batra U, Ray S, Prabhakar S R. Effect of Austenitization on Austempering of Copper Alloyed Ductile Iron. Journal of Materials Engineering and Performance, 2003, 12: 597-601.

[17] Stokes B, Gao N, Reed P A S. Effects of graphite nodules on crack growth behaviour of austempered ductile iron. Materials Science and Engineering: A, 2007, 445-446: 374-385.

[18] Hsu C-H, Lin K-T. A study on microstructure and toughness of copper alloyed and austempered ductile irons. Materials Science and Engineering: A, 2011, 528: 5706-5712.

[19] Kim S-J, Gil Lee C, Lee T-H, et al. Effect of $\mathrm{Cu}, \mathrm{Cr}$ and $\mathrm{Ni}$ on mechanical properties of 0.15 wt. $\%$ C TRIP-aided cold rolled steels. Scripta Materialia, 2003, 48: 539-544.

[20] Eric O, Sidjanin L, Miskovic Z, et al. Microstructure and toughness of CuNiMo austempered ductile iron. Materials Letters, 2004, 58: 2707-2711.

[21] Putatunda S K. Development of austempered ductile cast iron (ADI) with simultaneous high yield strength and fracture toughness by a novel two-step austempering process.

[22] Hsu C-H, Chuang T-L. Influence of Stepped Austempering Process on the Fracture Toughness of Austempered Ductile Iron. Metallurgical And Materials Transactions A, 2001, 32A: 2509-2514.

[23] Putatunda S K. Improvement in Stress Corrosion Crack Growth Resistance of an Austempered Cast Steel by a Novel Two-Step Austempering Process. Materials and Manufacturing Processes, 2003, 18: 667-684.
[24] Putatunda S K, Yang J H. A Novel Processing of Austempered Ductile Cast Iron (ADI). Materials Science Forum, 2003, 426432: 913-918.

[25] Elsayed A H, Megahed M M, Sadek A A, et al. Fracture toughness characterization of austempered ductile iron produced using both conventional and two-step austempering processes. Materials \& Design, 2009, 30: 1866-1877.

[26] Putatunda S K. Comparison of the Mechanical Properties of Austempered Ductile Cast Iron (ADI) Processed by Conventional and Step-Down Austempering Process. Materials and Manufacturing Processes, 2010, 25: 749-757.

[27] Ravishankar K S, Rao P P, Udupa K R. Improvement in fracture toughness of austempered ductile iron by two-step austempering process. International Journal of Cast Metals Research, 2013, 23: 330-343.

[28] Zhao Y, Guo Erjun. Effect of Austempered Process on Microstructure and Mechanical Properties of ADI (Master Thesis).Harbin University of Science and Technology, Harbin, Heilongjiang, China.

[29] Yang $\mathrm{H}$, Bhadeshia $\mathrm{H}$. Austenite grain size and the martensitestart temperature. Scripta Materialia, 2009, 60: 493-495.

[30] Breinan E M, Ansell G S. The Influence of Austenite Strength Upon the Austenite-Martensite Transformation in Alloy Steels. Metallurgical Transactions A,1970, 1: 1513-1520.

[31] Sandvik B P J. The Bainite Reaction in Fe-Si-C Alloys: The Secondary Stage. Metallurgical Transactions A, 1982, 13: 789_ 800 .

[32] Cheng L, Brakman C M, Korevaar B M, et al. The Tempering of Iron-Carbon Martensite; Dilatometric and Calorimetric Analysis. Metallurgical Transactions A, 1988,19: 2415-2426.

[33] Uwakweh O N C, Bauer J P, Génin J-M R. Mössbauer Study of the Distribution of Carbon Interstitials in Iron Alloys and the Isochronal Kinetics of the Aging of Martensite: The ClusteringOrdering Synergy. Metallurgical Transactions A, 1990, 21: 589602

[34] Jacques P J, Ladriere J, Delannay F. On the Influence of Interactions between Phases on the Mechanical Stability of Retained Austenite in Transformation-Induced Plasticity Multiphase Steels. Metallurgical and Materials Transactions A, 2001, 32: 2759-2768.

[35] Garin J L, Mannheim R L. Strain-induced martensite in ADI alloys. Journal of Materials Processing Technology, 2003: 143144: 347-351.

[36] Timokhina I B, Hodgson P D, Pereloma E V. Effect of Microstructure on the Stability of Retained Austenite in Transformation-Induced-Plasticity Steels. Metallurgical And Materials Transactions A, 2004, 35: 2331-2341.

[37] Sandvik B P J. The Bainite Reaction in Fe-Si-C Alloys: The Primary Stage. Metallurgical Transactions A, 1982, 13: 777787.

[38] Panneerselvam S, Martis C J, Putatunda S K, et al. An investigation on the stability of austenite in Austempered Ductile Cast Iron (ADI). Materials Science and Engineering: A, 2015, 626: 237-246.

[39] Lin C-K, Chang C-W. Influence of heat treatment on fatigue crack growth of austempered ductile iron. Journal Of Materials Science, 2002, 37: 709-716.

[40] Sherman D H, Cross S M, Kim S, et al. Characterization of the Carbon and Retained Austenite Distributions in Martensitic Medium Carbon, High Silicon Steel. Metallurgical and Materials Transactions A, 2007, 38: 1698-1711.

This work was financially supported by the National Natural Science Foundation of China (Grant Nos. 51374086 and 51674094). 